\title{
Nineteenth-Century Periodicals: Preservation Decision Making at College Libraries
}

\section{Donna Jacobs}

\begin{abstract}
Although the problem of deteriorating library materials has been the subject of numerous investigations at many of the nation's large research libraries in recent years, less attention has been given to the impact of the problem at small college libraries. This study investigates, by means of a survey, the preservation activities at the Oberlin Group of college libraries, specifically with respect to their nineteenth-century American and British periodicals collections. The information gathered by the survey and through an extensive review of the literature was used to develop a model for preservation decision making that takes into account the contextual elements of a small college library, the characteristics of the periodicals themselves, and the preservation options available. It was found that the decision-making process at a small college library is complex and multifaceted. Although there is no one answer that will meet the needs of every library, the questions that need to be asked are the same, and examination of those relevant questions will assist librarians in developing a decision-making strategy.
\end{abstract}

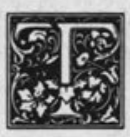

he crisis of deteriorating library materials that librarians are facing today was predicted centuries ago. As early as the twelfth century, the emperor of the Occident, Frederick I, Barbarossa, prohibited the use of paper in deeds and charters because he feared the medium too perishable. In 1823, John Murray warned readers of Gentlemen's Magazine of the state of "that wretched compound called Paper," saying that "a century more will not witness the volumes printed within the last twenty years." ${ }^{11}$ Awareness of the problem and commitment to action grew so gradually that in 1946, Pelham Barr commented "Silence, rarely broken, seems to surround the subject of book conservation." 2 Today libraries face a crisis of major proportions. The extent of the problem can be seen in an inventory of the 13.5 million volumes at the Library of Congress, which revealed that three million volumes are too brittle to handle, and 70,000 volumes are added to that group each year. ${ }^{3}$ The results of a survey of the Yale University collections showed that over $37 \%$ of their $7,725,000$ volumes had brittle paper, $82.6 \%$ had acidic paper, and $8 \%$ had broken bindings. ${ }^{4}$

In 1970, Edwin Williams summarized the discussion of the deterioration of library materials in one sentence: "Everything in library collections is deteriorating today, was deteriorating yesterday, and will continue to deteriorate tomorrow

Donna Jacobs is Science/Reference Librarian at Andrews Library at the College of Wooster, Wooster, Ohio 44691. 
although we ought to retard the process." ${ }^{15}$ Unfortunately, when one moves from discussion of the topic to action, the problem cannot be so neatly summarized, and the solutions are often unknown, debatable, or unattainable for a variety of reasons.

The physical condition of the volumes brings the question of their fate to a library staff's attention. While questions about the causes of deterioration and the availability of appropriate alternatives to halt or reverse the process must be addressed, an equally important consideration is the works themselves. Such factors as the intellectual content of the works, their intrinsic value, and their availability in original and alternative formats must also be investigated. In addition, such contextual elements as the mission and priorities of the library in question, and its policies and resources, are important factors in preservation decision making. The complexity of the problem seems to require a model to assist in the decision-making process. The objective of this project, which was prompted by an assessment of the nineteenth-century American and British periodicals collection at the author's library, was to develop a logical and efficient model for making preservation decisions with respect to nineteenth-century periodicals collections at college libraries.

\section{LITERATURE REVIEW}

The central focus of this study is the question of how preservation decisions should be made. This question has been addressed in recent years by Dan Hazen, Ross Atkinson, and Margaret Child, among others. In a 1982 article, Hazen described the preservation selection process in terms of collection development. He saw the primary responsibility of collection development in the preservation process as one of making item-by-item preservation selection decisions on the basis of criteria similar (but not identical) to the criteria used for the selection of current materials. Collection development involves librarians deciding which documents to acquire, while selection for preservation involves determining which documents least deserve destruction. ${ }^{6}$ Hazen listed academic activity, traditional collecting strengths, availability and cost, alternatives (to purchasing or to local preservation), and discipline-specific models of access to information as the five distinct, interrelated factors to which both collection development and preservation respond within a given resource base and allocation structure?

Atkinson pointed out that some of the values involved in selecting for preservation are at odds with those of collection development and that a negative preservation decision represents a reversal of a series of positive decisions made throughout the history of the text. ${ }^{8} \mathrm{He}$ identified two decisions that must be made in selecting for preservation, with each consisting of both technical and critical components. The first decision is the identification for preservation-technically, what needs to be preserved, and critically, what should be preserved. The second decision is the determination of the mode of preservation-technically, which modes are possible, and critically, which modes should be used.

In answer to the fundamental question, from the standpoint of collection development, of why certain items should survive while others should not, Atkinson suggested a typology of preservation based on three different categories of library materials which should be preserved. ${ }^{9}$ His Class 1 preservation aims at preserving materials or groups of materials that have a high economic value, as well as level-five collections, as defined by the RLG Conspectus,$^{10}$ the value of which lies in the comprehensiveness of the materials rather than in any single item's individual intrinsic value. Child expanded this definition somewhat to include "several nonmonetary but important research values deriving from artifactual characteristics which compel preservation in the original format." ${ }^{\prime 11}$ Class 2 preservation focuses on higher-use items that are currently in demand for classwork and research purposes, the need for preservation arising mainly from overuse. Class 3 preservation maintains for posterity lower-use research materials. Atkinson saw these materials as the source for cooperative preservation, with microfilm as the primary mode of 
preservation. He pointed out that selection criteria for Class 3 preservation are less easily defined than for Classes 1 or 2 because "we are all products of an age, a nation, and a profession that has [sic] become increasingly unwilling to accept or to apply absolutes." 12

According to Child, two factors complicate selection for preservation. First, the extraordinary expansion of American research since World War II has increased the subject matter and sources considered appropriate for study. And second, the technological possibility of saving everything forces difficult choices with respect to what will be saved and what will be allowed to deteriorate. ${ }^{13}$ Atkinson brought home the importance of this situation by pointing out that, in making preservation decisions today, libraries control the future because "the future will only be able to understand and define itself in relation to what [libraries] give it."14

\section{The technological possibility of saving everything forces difficult choices with respect to what will be saved and what will be allowed to deteriorate.}

In recent years, various research libraries have conducted preservation studies of their collections, many based on Pamela Darling's manual Preservation Planning Program..$^{15}$ Preservation surveys, and special programs implemented at different types and sizes of libraries are discussed in Gay Walker, et. al. (Yale); L. Nainis and L. A. Bedard (Georgetown University Law Library); Charlotte Brown, and Brown and Janet Gertz (Franklin and Marshall); and Jan Merrill-Oldham (University of Connecticut). ${ }^{16}$ In addition, preservation studies at Yale, Stanford, Berkeley, and the Library of Congress are discussed in the proceedings of an April 1983 conference, edited by Jan Merrill-Oldham and Merrily Smith. ${ }^{17}$

Of particular interest was the study conducted by Brown and Gertz at the ShadekFackenthal Library of Franklin and Marshall College, the purpose of which was to test the applicability of the Atkinson model for smaller academic libraries. The results of the study suggested that the Atkinson typology is indeed workable at smaller institutions, and that small college libraries may have significant amounts of materials that fall into Class 3 and that may be of substantial research value to the scholarly community.

\section{METHOD}

Most of the preservation studies that have been conducted to date have focused on research collections at large universities. Because the mission of college libraries places more emphasis on current teaching and research, and proportionally less on archival functions, one would expect different priorities to motivate the preservation activities at these smaller institutions. In order to collect information about the preservation activities of smaller college libraries, a questionnaire was sent to the libraries that make up the Oberlin Group, an informal association of directors of more than 60 college libraries across the country with similar characteristics and needs. These libraries serve campuses with enrollments ranging from around 500 to 3,400 students, although most fall between 1,000 and 2,000 .

The six-part questionnaire sought to determine the extent to which concern for the preservation needs of nineteenth-century American and British periodicals influence collection management policies, and which preservation measures are used. The survey also asked for information regarding the availability of preservation resources, such as trained personnel, facilities, and specific budget allocations, at Oberlin Group institutions, as well as the extent to which a decision-making structure exists at these libraries. Finally, the questionnaire sought to determine the use of nineteenthcentury American and British periodicals in support of course work and faculty and student research, the condition of these volumes, and how widely they are heldin both paper and microformat-at the Oberlin Group libraries.

The information obtained by the survey was tabulated and analyzed using 
TABLE 1

CRITERIA FOR DETERMINING

CIRCULATION POLICY FOR NINETEENTH-CENTURY PERIODICALS

\begin{tabular}{|c|c|c|c|c|c|c|c|c|}
\hline \multirow[b]{3}{*}{ Criteria } & \multicolumn{6}{|c|}{ Rank } & & \\
\hline & \multicolumn{3}{|c|}{ First or Second } & \multicolumn{3}{|c|}{ Third, Fourth, or Fifth } & \multicolumn{2}{|c|}{ Total } \\
\hline & $\mathrm{R} \%$ & $\mathrm{~N}$ & $\mathrm{C} \%$ & $\mathbf{R} \%$ & $\mathrm{~N}$ & $\mathrm{C} \%$ & $\mathrm{~N}$ & $\mathrm{C} \%$ \\
\hline Age & 21 & 3 & 8 & 79 & 11 & 34 & 14 & 20 \\
\hline Physical condition & 71 & 12 & 32 & 29 & 5 & 16 & 17 & 25 \\
\hline Intrinsic value & 94 & 15 & 41 & 6 & 1 & 3 & 16 & 23 \\
\hline Use & 38 & 5 & 14 & 62 & 8 & 25 & 13 & 19 \\
\hline Space & 22 & 2 & 5 & 78 & 7 & 22 & 9 & 13 \\
\hline Total & & 37 & & & 32 & & 69 & \\
\hline
\end{tabular}

Chi-square $=22.93 ; \mathrm{p}<0.001 ;$ Cramer's Phi $=0.58$

$\mathrm{N}$ is the number of responses in a given category, $\mathrm{R} \%$ is the row percent, and $\mathrm{C} \%$ is the column percent.

the spreadsheet program EXCEL, as described in the next section. Using this information and the information obtained in the literature review, a model was developed that describes the elements involved in preservation decision making at small liberal arts colleges, especially with respect to nineteenth-century American and British periodicals.

\section{RESULTS AND ANALYSIS}

The high return rate of questionnaires $(85 \%)$ is an indication that most of the libraries in the Oberlin Group recognize the problem of the deterioration of nineteenthcentury periodicals and are interested in what other college libraries are doing about preservation of these journals. Clearly, the condition of the collections reflected a need to increase preservation activities. Fully $75 \%$ of the libraries described the condition of their paper volumes as fair or poor. Given this fact, the data provide revealing information on the preservation policies and activities of the member libraries.

\section{Circulation of Nineteenth- Century Periodicals}

In analyzing the circulation policies of the Oberlin Group libraries, it was found that, of the 56libraries that responded to the survey, $7(13 \%)$ allow all of their nineteenthcentury periodicals to circulate, $12(21 \%)$ allow some to circulate, and $37(66 \%)$ allow none to circulate. While $61 \%$ of the respondents reported a blanket circulation policy for all journals, 37\% ranked their criteria for determining circulation policy for nineteenth-century periodicals. The responses are summarized in table 1. It was necessary to group the rankings ("first or second," and "third, fourth, or fifth") due to small cell sizes.

A glance at each of the criteria individually reveals that those ranking intrinsic value ranked it either first or second in importance $94 \%$ of the time. Physical condition was ranked either first or second $71 \%$ of the time. These two characteristics were clearly the most important criteria for determining circulation policy for nineteenth-century periodicals. Use, age, and space were less important. Comparing all variables, intrinsic value and physical condition were ranked first or second $41 \%$ and $32 \%$ of the time, respectively. On the other hand, age, use, and space were less important, being ranked third, fourth, or fifth $34 \%, 25 \%$, and $22 \%$, respectively. Based on $\chi^{2}$ analysis, there is a statistically significant association between high rank and both intrinsic value and physical condition. The Cramer's phi value of .58 indicates that the strength of the relationship is moderate.

\section{Shelving Nineteenth- \\ Century Periodicals}

Of the 64 responses recorded, $73 \%$ shelved nineteenth-century periodicals either with 
TABLE 2

CRITERIA FOR DETERMINING SHELVING POLICY FOR NINETEENTH-CENTURY PERIODICALS

\begin{tabular}{|c|c|c|c|c|c|c|c|c|}
\hline \multirow[b]{3}{*}{ Criteria } & \multicolumn{6}{|c|}{ Rank } & \multirow{2}{*}{\multicolumn{2}{|c|}{ Total }} \\
\hline & \multicolumn{3}{|c|}{ First or Second } & \multicolumn{3}{|c|}{ Third, Fourth or Fifth } & & \\
\hline & $\mathbf{R} \%$ & $\mathrm{~N}$ & $\mathrm{C} \%$ & $\mathrm{R} \%$ & $\mathrm{~N}$ & $\mathrm{C} \%$ & $\mathrm{~N}$ & $\mathrm{C} \%$ \\
\hline Age & 40 & 10 & 15 & 60 & 15 & 26 & 25 & 20 \\
\hline Physical condition & 59 & 17 & 26 & 41 & 12 & 21 & 29 & 24 \\
\hline Intrinsic value & 72 & 18 & 27 & 28 & 7 & 12 & 25 & 20 \\
\hline Use & 48 & 11 & 17 & 52 & 12 & 24 & 23 & 19 \\
\hline Space & 48 & 10 & 15 & 52 & 11 & 19 & 21 & 17 \\
\hline Total & & 66 & & & 57 & & 123 & \\
\hline
\end{tabular}

Chi-square $=6.17 ; \mathrm{p}<0.2 ;$ Cramer's Phi $=0.22$

$\mathrm{N}$ is the number of responses in a given category, $\mathrm{R} \%$ is the row percent, and $\mathrm{C} \%$ is the column percent.

other bound periodicals or interfiled with the general collection, while $10 \%$ shelved them in a storage area, either remote or in-house. Only $16 \%$ reported shelving all or most of their nineteenthcentury periodicals in a restricted special collection, although others reported having a few selected titles in a special collection or in the rare books room. Responses to this question indicate that few of the libraries surveyed have a special storage location for nineteenth-century periodicals.

Table 2 summarizes rankings of criteria for determining shelving policy for nineteenth-century periodicals. Again, it was necessary to group rankings due to small cell sizes. Considering each of the criteria individually, when intrinsic value and physical condition were chosen, they tended to be ranked slightly higher than other criteria. Intrinsic value was ranked first or second $72 \%$ of the time, and physical condition was ranked first or second $59 \%$ of the time. Space and use were ranked first or second slightly less than half of the time. Age tended to be ranked lower, ranking first or second only $40 \%$ of the time.

Comparing all variables revealed that physical condition and intrinsic value were the most important criteria for determining shelving policy for nineteenthcentury periodicals. Physical condition, chosen in $52 \%$ of the surveys, accounted for $26 \%$ of the first or second rankings.
Intrinsic value, chosen in $45 \%$ of the surveys, accounted for $27 \%$. Use was ranked first or second in $17 \%$ of the surveys that ranked criteria, and age and space each accounted for $15 \%$. Although, as with circulation policy, physical condition and intrinsic value seem to be more important factors in determining shelving policy, the relationships were not statistically significant.

\section{Preservation Resources}

Preservation resources, including trained personnel, facilities, and funding, are essential elements in any preservation decisionmaking model. Generally speaking, preservation efforts at many of the surveyed libraries seem to be hampered in varying degrees by a lack of trained personnel and preservation facilities and by budgetary constraints. In analyzing the personnel resources of the Oberlin Group libraries, $18 \%$ were found to have no professional librarians performing preservation duties, $65 \%$ had one or two librarians responsible for performing preservation tasks as part of their jobs, and only $17 \%$ had three or more librarians performing preservation tasks. Fifty-five percent of the responding libraries reported that, of those individuals whose jobs actually involve preservation and conservation activities, one person had some preservation training. Only $23 \%$ had more than one person trained, and $22 \%$ reported that 
TABLE 3

RELATIONSHIP BETWEEN ABSENCE OF PRESERVATION FACILITIES AND PREFERRED PRESERVATION MEASURES

\begin{tabular}{lrrrrrrrr}
\hline & \multicolumn{9}{c}{ Inadequate facilities } \\
\cline { 2 - 9 } Preservation Measures & R\% & \multicolumn{1}{c}{ Yes } & C & R\% & N & C\% & N & C\% \\
\hline Restricted access & 27 & 4 & 18 & 73 & 11 & 46 & 15 & 33 \\
In-house mending & 73 & 11 & 50 & 27 & 4 & 17 & 15 & 33 \\
Commercial rebinding & 57 & 4 & 18 & 43 & 3 & 13 & 7 & 15 \\
Protective enclosures & 20 & 1 & 5 & 80 & 4 & 17 & 5 & 11 \\
Microfilm & 50 & 2 & 9 & 50 & 2 & 8 & 4 & 9 \\
$\quad$ Total & & 22 & & & 24 & & 46 & \\
\hline
\end{tabular}

Chi-square=8.41; p $<0.1$; Cramer's Phi=0.43

$\mathrm{N}$ is the number of responses in a given category, $\mathrm{R} \%$ is the row percent, and $\mathrm{C} \%$ is the column percent

none of the personnel performing preservation tasks had training.

Forty-six percent of the respondents felt that the absence of preservation facilities or equipment had actually been a factor in preservation decision making. They cited limitations in trained staff, a lack of preservation labs and environmentally controlled stack areas, and a lack of time and funds. Those that said that resources were not a factor in decision making either have such preservation facilities or do not see preservation as a priority. A few reported that new buildings are planned or are under construction that will include preservation facilities. Only $36 \%$ of the libraries reported having portions of their budgets specifically allocated for preservation, and some of those indicated that the amounts were not sufficient. Several noted that preservation costs were taken from the binding allocations in their budgets.

\section{Preservation Measures}

When asked to identify the preservation measures used for nineteenth-century periodicals, the four most commonly chosen were in-house mending, commercial rebinding, restricted access, and protective enclosures. Of the preservation measures most often used, in-house mending and restricted access together accounted for $62 \%$ of the responses, while commercial rebinding and protective enclosures accounted for $24 \%$.
An analysis of the relationships between the available resources and the preferred methods of preservation revealed that the absence of adequate facilities has some relationship to the preservation measures most often chosen. This is evident particularly in the choice between restricted access and in-house mending, each of which was chosen in 15 of the 48 surveys used in this analysis. As shown in table 3, of those libraries that chose in-house mending as their most often used preservation measure, $73 \%$ also responded that the absence of adequate facilities was a factor in their preservation decision making.

\section{Preservation efforts at many of the surveyed libraries seem to be hampered in varying degrees by a lack of trained personnel and preservation facilities and by budgetary constraints.}

On the other hand, of those that chose restricted access, $73 \%$ seemed to feel that they had adequate facilities. Neither the number of trained staff nor a specific budget allocation for preservation was a significant factor, overall, in the choice of one preservation measure over another.

\section{Preservation Decision Making}

With respect to preservation decision making, 20\% of the libraries had conducted studies of the collection preserva- 
TABLE 4

RELATIONSHIP BETWEEN PRESERVATION NEEDS STUDY AND INDIVIDUAL RESPONSIBLE FOR PRESERVATION DECISIONS

\begin{tabular}{|c|c|c|c|c|c|c|c|c|}
\hline \multirow[b]{3}{*}{ Person Responsible? } & \multicolumn{8}{|c|}{ Preservation Study } \\
\hline & \multicolumn{3}{|c|}{ Yes } & \multicolumn{3}{|c|}{ No } & \multicolumn{2}{|c|}{ Total } \\
\hline & $\mathbf{R} \%$ & $\mathrm{~N}$ & $\mathrm{C} \%$ & $\mathbf{R} \%$ & $\mathrm{~N}$ & $\mathrm{C} \%$ & $\mathrm{~N}$ & $\mathrm{C} \%$ \\
\hline Yes & 38 & 5 & 42 & 62 & 8 & 19 & 13 & 24 \\
\hline No & 17 & 7 & 58 & 83 & 35 & 81 & 42 & 76 \\
\hline Total & & 12 & & & 43 & & 55 & 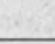 \\
\hline
\end{tabular}

Chi-square $=2.76$; $\mathrm{p}<0.1$; Cramer's Phi $=0.22$

$\mathrm{N}$ is the number of responses in a given category, $\mathrm{R} \%$ is the row percent, and $\mathrm{C} \%$ is the column percent.

TABLE 5

RELATIONSHIP BETWEEN PRESERVATION NEEDS STUDY AND BUDGET ALLOCATION

\begin{tabular}{|c|c|c|c|c|c|c|c|c|}
\hline \multirow[b]{3}{*}{ Person Responsible? } & \multicolumn{8}{|c|}{ Preservation Study } \\
\hline & \multicolumn{3}{|c|}{ Yes } & \multicolumn{3}{|c|}{ No } & \multicolumn{2}{|c|}{ Total } \\
\hline & $\mathrm{R} \%$ & $\mathrm{~N}$ & $\mathrm{C} \%$ & $\mathbf{R} \%$ & $\mathrm{~N}$ & $\mathrm{C} \%$ & $\mathrm{~N}$ & $\mathrm{C} \%$ \\
\hline Yes & 38 & 8 & 73 & 60 & 12 & 27 & 20 & 36 \\
\hline No & 9 & 3 & 27 & 91 & 32 & 73 & 35 & 64 \\
\hline Total & & 11 & 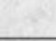 & & 44 & & 55 & \\
\hline
\end{tabular}

Chi-square=7.86; $\mathrm{p}<0.01$; Cramer's Phi $=0.2$

$\mathrm{N}$ is the number of responses in a given category, $\mathrm{R} \%$ is the row percent, and $\mathrm{C} \%$ is the column percent.

tion needs in the last 5 years, but only $12 \%$ had assessed the preservation needs of their nineteenth-century periodicals collection. Only one of the 56 libraries has a written policy to guide preservation decision making, although two others are in the process of developing such a policy.

In response to questions regarding who makes preservation decisions, $13(24 \%)$ of the libraries reported having an individual whose major responsibility is to evaluate and select materials for preservation. Forty-six respondents $(62 \%)$ reported having an individual (or an individual job) who is responsible for making preservation decisions, though not as a major part of his or her responsibilities, and $37 \%$ reported that preservation decision making was shared among two or more individuals (or individual job titles). Many more individuals are involved in preservation decision making than were anticipated when the questionnaire was designed, and responsibility is often shared. Individuals named as being involved in decision mak- ing included the reference librarian, technical services librarian, collection development officer, bibliographer, director, serials staff (which handles mending), college archivist, special collections librarian, circulation head, and collection management librarian.

Two variables were found to be weakly associated with libraries that have conducted studies of their preservation needs. Table 4 shows a weak association between having a person whose primary responsibility is making preservation decisions and whether or not a study of preservation needs has been conducted. The data indicate that those libraries that have a person responsible for preservation are more likely to have conducted such a study than those that do not. Also, of those libraries that have not conducted a study, more than $80 \%$ do not have a person responsible for making preservation decisions. It is difficult to tell from this data what the cause and effect relationship might be; that is, does having a person responsible for 
preservation motivate a preservation study, or do the results of a study reveal the need for such a person?

A more significant relationship was found to exist between a preservation needs study and a specific budget allocation for preservation. The data in table 5 show that $73 \%$ of those libraries that have conducted a study of their preservation needs have budget allocations for preservation, and that $73 \%$ of those who have not conducted such a study do not have preservation budgets. Further, while $40 \%$ of those that have budgets have conducted a study, $91 \%$ of those who do not have budgets have not conducted a study. Again, it is difficult to tell whether conducting a study motivates the allocation of funds for preservation or is dependent on it.

\section{Summary}

The data obtained in the survey give valuable information about the policies, procedures, and resources currently being used for preservation at the Oberlin Group libraries, particularly with respect to nineteenth-century periodicals. The participating libraries, in general, demonstrate a concern for the materials' intrinsic value and physical condition in their circulation policies and, to a lesser extent, in their shelving policies. Most of the libraries are hampered in their efforts to deal with the situation by limitations in funding, facilities, or trained personnel. The preservation measures used most often are in-house mending and restricted access, along with commercial rebinding and protective enclosures.

It is especially revealing that there is very little identifiable structure for decision making reported by the libraries. Only $20 \%$ have conducted a study of the their collection's preservation needs within the last 5 years, and only one of the 56 libraries responding has a written preservation policy, although two others are in the process of drafting one. Further, the responsibility for preservation decision making is not well defined. Within each library, decision making may be shared among several individuals or job titles, including those involved in bibliographic, technical service, collection management, administrative, preservation, and archival functions. Likewise, among the different libraries, job titles of those involved in preservation decision making vary widely.

The results of this survey indicate the need for a model describing the elements of preservation decision making to help college libraries choose appropriate alternatives for the preservation of their collections, in general, and their nineteenth-century periodicals, in particular.

\section{THE MODEL}

The question posed in this study is, "How does a college library, with preservation options severely limited by available resources, make preservation selections with respect to nineteenth-century periodicals?" Using Atkinson's typology, one would tend to place nineteenth-century periodicals primarily in Class 3-lower use research materials - with some titles or some individual volumes fitting into Class 1 -high economic value materials - because of artifactual characteristics. This would suggest that blanket decisions be made for all nineteenth-century periodicals, as opposed to the item-by-item decisions necessary in Class 2 -higher use items. Furthermore, in considering Class 3 preservation, both Atkinson and Child focus on a national cooperative microfilming project as the preferred mode of preservation. But is the preservation decision-making model that is used in a national cooperative project appropriate for a college library considering preservation options for nineteenth-century periodicals? Can all or most of these titles be placed in one class? Can a given periodical title be placed in a particular class that is appropriate for all libraries? Are the solutions used in one college library appropriate for all college libraries? If the Atkinson model, helpful as it is, is not sufficient for answering these questions in the context of a small college library, what factors need to beconsidered in making preservation decisions for nineteenth-century periodicals?

College libraries face difficult decisions in determining which preservation options are appropriate for nineteenth-century periodicals. The results of the Oberlin Group survey show that the periodicals are widely held, especially in older collections, and are in fair to poor condition. The 
data revealed that nineteenth-century periodicals are used infrequently for either teaching or research. These materials face the same physical preservation problems as they do in large research libraries, but in the context of a small college, they represent a proportionally larger commitment of time and resources, while possibly falling outside the major mission of the institution to support current teaching and research..$^{18}$

The factors involved in the selection of nineteenth-century periodicals for preservation fall into three broad, overlapping categories. The first category concerns details of the context in which the decisions are to be made - in this case, the context of the small liberal arts college library. The second category deals with the characteristics of the documents being considered for preservation - the nineteenth-century American and British periodicals. Finally, it is necessary to know of the various preservation options that are available. These factors are diagrammed in figure 1.

Solutions to the problems posed by preservation will differ from one college library to another, based on its assessment of its needs and priorities. The Oberlin Group survey revealed, however, that very little identifiable structure for decision making exists in college libraries. Most have not studied their preservation needs, and only one of the 56 respondents has a written preservation policy. Responsibility for decision making does not appear to be clearly defined, and most of the libraries are hampered in their preservation efforts by a lack of funds, facilities, and trained personnel.

One important element, then, in developing a decision-making structure must be to assess the institutional context within which preservation decisions are to be made.

- What programs does the library support?

- What is the relative importance of its different programs?

- What are the institution's priorities with respect to course work support, and faculty and student research?

- Does the library have a role in serving as a repository for low-use, long-term research materials, in addition to supporting current sources and activities?
- Are these priorities clearly defined in written collection development and preservation policies?

- Are the priorities supported by collection management policies regarding circulation, shelving, and maintenance of delicate materials?

- Can the preservation priorities be supported by the available resources including funding, facilities, and trained personnel?

By examining these contextual elements, one can begin to develop a decision-making structure. Categories of materials that should be preserved start to emerge from the programmatic priorities as expressed in the collection development and preservation policies. The collection management structure will determine who will be responsible for preservation decision making. The available resources will suggest limitations on the possible preservation options.

It is within this contextual framework that the nineteenth-century periodicals are evaluated for value, availability, and physical condition, the second element in the decision-making structure.

- Does the periodical have economic or research value that would dictate preservation in its original format?

- Does it support current programs or research projects at the institution?

- Is it part of, or does it support, a special collection or an area of traditional strength in the collection?

- What is the periodical's scope?

- What is its publication history, including title changes and merges?

- Who were its editors, publishers, and major contributors?

- Are there special features, such as illustrations or first appearances of classic works?

- Where is the periodical indexed?

-What are the local holdings?

- Is it readily available through interlibrary loan?

- Are reprints of articles available commercially?

- Is the journal available in microform?

- What is the physical condition of the paper and bindings?

Evaluation of the periodicals themselves - their value, availability, and physical condition-further defines which 


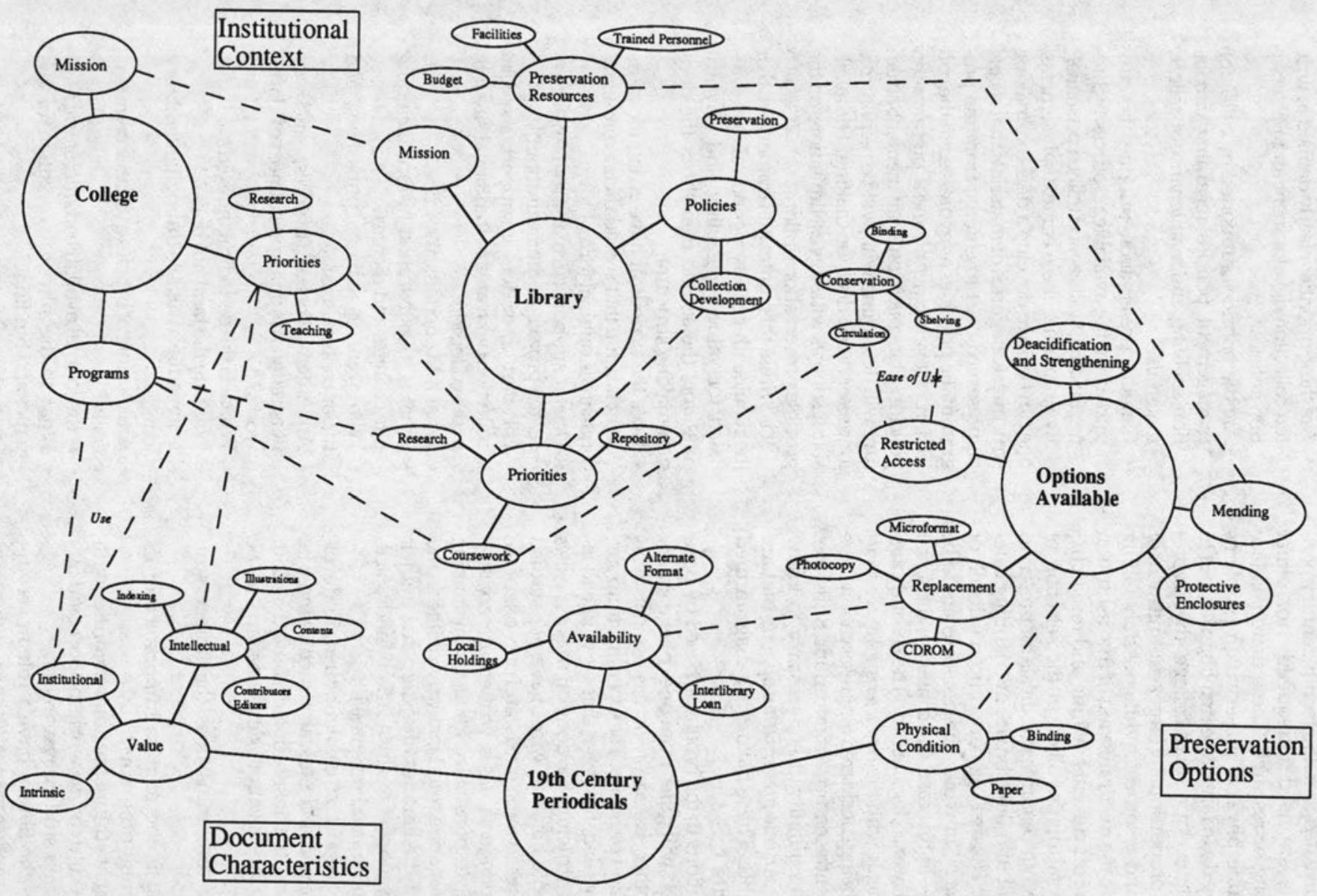

Figure 1: A model for preservation decision making. Selection for preservation must take into account the institutional context, the characteristics of the documents in question, and the preservation options that are available. 
items should be preserved, the extent of the preservation need, and the preservation methods appropriate for a given journal.

The final decision regarding the most appropriate methods of preservation is based on the techniques available and a comparison of their merits within the context of the institution and the documents being preserved.

- Which of the available techniques meets the needs of the periodicals?

- What is the cost of the appropriate technique(s)?

-What is the quality of the end product?

- Which alternative offers the most protection to the document and its contents, while interfering least with patron access?

- Which alternative is easiest to use?

- Which alternative(s) is (are) possible within the limitations of the available resources?

\section{CONCLUSION}

This study was motivated by a specific concern for the preservation of nineteenth-century American and British periodicals at a small liberal arts college. Initially, it was hoped that a model could be developed that would provide a formula for preservation decision making. Not surprisingly, the process of making preservation decisions for nineteenthcentury periodicals at small college libraries, with preservation options limited by available resources, was found to present a complex, multifaceted problem.

The model proposed here does not provide such a formula. The data suggest that no fixed formula can be devised that would apply in every case to resolve conflicts between, for example, the institutional context and the characteristics of the documents, although common important considerations emerge. Indeed, it is sometimes difficult to separate institutional context and document characteristics. One institution from the Oberlin Group reported having an extensive collection of Norwegian-American periodicals in need of preservation. The primary mission of this small college normally would preclude investing heavily in pres- ervation of documents that get little use by the faculty and students of that institution. However, the fact that these items are not widely held and are of historical significance in the area might justify a preservation effort that would be more commonly undertaken by a research library.

The questions to be considered in each category of the model-institutional context, document characteristics, and preservation options - apply to any library, large or small, or to any group of documents. The answers to the questions posed, however, will differ depending on the primary mission of the library and the institution it serves, the characteristics of the documents being considered, and the preservation options available. While no library can afford to preserve everything, large research libraries may find that materials such as nineteenth-century periodicals are used heavily enough to warrant some measure of preservation. Or, if judged to fit into Atkinson's Class 1 or Class 3, they may be preserved as part of that library's mission to serve as a repository for loweruse research materials.

This repository function falls outside the primary mission of most college libraries. A number of the respondents to the Oberlin Group survey commented that they felt that, except in special cases, preservation is more appropriately a concern of research libraries. The survey showed that many librarians in the Oberlin Group were hampered in their preservation efforts by a lack of resources and decision-making structure. One librarian, who reported that space was the major criterion in setting shelving and circulation policies for nineteenth-century periodicals, expressed concern that the lack of space, rather than the needs of the documents, motivated the library's decision making. Those libraries that were able to take some active preservation measures for these journals seemed to be making item-by-item decisions about which titles to preserve and how, rather than making the blanket decisions implied by the Atkinson model.

Although the model proposed here does not provide a formula for making preservation decisions that will meet the needs of every college library, it does illustrate 
the three overlapping areas of concern that must be addressed. While the answers to the questions posed in each of these categories will be different for each institution, the questions themselves will besimilar. Hopefully, an examination of the relevant questions will help college librarians develop goals and a practical, systematic strategy for preservation decision making appropriate for the institutions they serve.

A copy of the survey can be obtained from Donna Jacobs, Science/Reference Librarian at Andrews Library, The College of Wooster, Wooster, Ohio 44691.

\section{REFERENCES AND NOTES}

1. John Murray, "On the Bad Composition of Paper," Gentlemen's Magazine 93:21-22 (July 1823).

2. Pelham Barr, "Book Conservation and University Library Administration," College $\mathcal{E}$ Research Libraries 7:214 (July 1946).

3. Philip H. Abelson, "Brittle Books and Journals," Science 238:595 (Oct. 30, 1987).

4. Gay Walker, et. al., "The Yale Survey: A Large-Scale Study of Book Deterioration in the Yale University Library," College \& Research Libraries 46:128 (March 1985).

5. Edwin E. Williams, "Deterioration of Library Collections Today," in Deterioration and Preservation of Libraries, ed., Howard W. Winger and Richard Daniel Smith (Chicago: Univ. of Chicago Pr., 1970), p.3.

6. Dan C. Hazen, "Collection Development, Collection Management and Preservation," Library Resources \& Technical Services 26:6-7 (Jan./Mar. 1982).

7. Ibid., p.7.

8. Ross W. Atkinson, "Selection for Preservation: A Materialistic Approach," Library Resources \& Technical Services 30:342 (Oct./Dec. 1986).

9. Ibid., p.344.

10. Nancy E. Gwinn and Paul H. Mosher, "Coordinating Collection Development: The RLG Conspectus," College \& Research Libraries 44:140 (Mar. 1983).

11. Margaret S. Child, "Further Thoughts on 'Selection for Preservation: A Materialistic Approach,'" Library Resources \& Technical Services 30:355 (Oct./Dec. 1986).

12. Atkinson, "Selection for Preservation," p.348.

13. Child, "Further Thoughts," p.356-57.

14. Atkinson, "Selection for Preservation," p.347.

15. Pamela W. Darling with Duane E. Webster, Preservation Planning Program: An Assisted Self-Study Manual for Libraries (Washington, D.C.: Assn. of Research Libraries, Office of Management Studies, 1982).

16. Walker, et.al., 111-132; L. Nainis and L. A. Bedard, "Preservation Book Survey in an Academic Law Library," Law Library Journal 78:243-59 (Spring 1986); Charlotte B. Brown, "The Preservation Program at Franklin and Marshall College," Conservation Administration News 30:6-7 (July 1987); Charlotte B. Brown and Janet Gertz, "Selection for Preservation: Applications for College Libraries," accepted for presentation and publication at ACRL Fifth National Conference, Cincinnati, April 1989; Jan MerrillOldham, Conservation and Preservation of Library Materials: A Program for the University of Connecticut Libraries (Storrs: Univ. of Connecticut Library, 1984).

17. Jan Merrill-Oldham and Merrily Smith, eds., The Library Preservation Program: Models, Priorities, Possibilities (Chicago: American Library Assn., 1985).

18. Brown and Gertz, "Selection for Preservation," p.8. 